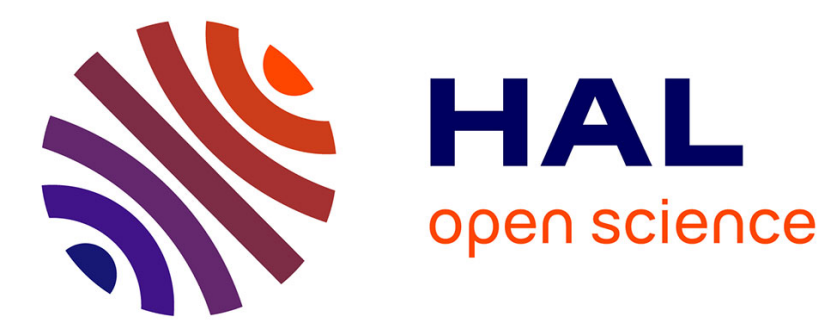

\title{
Neuro-image: Milky Effluent after Therapeutic Plasma Exchange
}

\author{
Nicolas Weiss, Sacha Posener, Loïc Le Guennec
}

\section{To cite this version:}

Nicolas Weiss, Sacha Posener, Loïc Le Guennec. Neuro-image: Milky Effluent after Therapeutic

Plasma Exchange. Acta Neurologica Belgica, 2021, 10.1007/s13760-021-01679-1 . hal-03268545

\section{HAL Id: hal-03268545 \\ https://hal.sorbonne-universite.fr/hal-03268545}

Submitted on 23 Jun 2021

HAL is a multi-disciplinary open access archive for the deposit and dissemination of scientific research documents, whether they are published or not. The documents may come from teaching and research institutions in France or abroad, or from public or private research centers.
L'archive ouverte pluridisciplinaire HAL, est destinée au dépôt et à la diffusion de documents scientifiques de niveau recherche, publiés ou non, émanant des établissements d'enseignement et de recherche français ou étrangers, des laboratoires publics ou privés. 


\section{Neuro-image : Milky Effluent after Therapeutic Plasma Exchange}

Sacha POSENER, M.D. 1,2 and Loïc LE GUENNEC, M.D.Ph.D. 1,2

1 Sorbonne Université, Faculté de médecine PARIS, France

2 Médecine Intensive Réanimation Neurologique, Hôpital de la Pitié Salpêtrière, Assistance Publique-Hôpitaux de Paris, Paris, France

A 29-year-old woman was admitted to our intensive care unit for new-

onset refractory status epilepticus (NORSE) requiring general anesthesia. Diagnostic workup found anti-NMDA-receptor antibodies. Because of ongoing seizure activity despite highdoses of propofol, midazolam and ketamine, therapeutic plasma exchange (TPE) was initiated every 3 days. A ketogenic diet (KD) was also started to optimize seizure control. On the fifth day of this regimen, TPE effluent turned milky white. Laboratory results found a triglyceride level of $>1500$ milligram-per-deciliter (reference range $35-146$ ). A diagnosis of KD-induced hypertriglyceridemia was made and the diet was discontinued. Triglyceride levels subsequently decreased to 350 milligram-per-decilitre the following day, and effluent color had normalized on later TPE. Propofol-Related-Infusion-Syndrome was also considered, however, the diagnosis was excluded given the decrease of triglyceride levels although Propofol doses were unchanged. ${ }^{1}$

This is, to our knowledge, the first report of lactescent plasma during TPE for NMDAreceptor encephalitis in a patient undergoing a KD. Latescent plasma is a sign of severe hypertriglyceridemia and can occur when triglyceride levels reach $>1000 \mathrm{mg} / \mathrm{dL} .{ }^{2}$ Causes include inborn errors of metabolism and acquired disorders, notably iatrogenic causes such as infusions of lipid emulsions or Propofol-Related-Infusion-Syndrome. ${ }^{3}$ KD complicated by 
severe hypertriglyceridemia has been observed anecdotally, and given the timing and resolution of symptoms after discontinuation, seemed like the more likely candidate.

Acute pancreatitis is an acute and potentially life-threatening complication of severe hypertriglyceridemia. It is caused by the production of toxic by-products of triglyceride metabolism by pancreatic lipase. According to international guidelines, acute pancreatitis in this context can be managed by a low-fat diet and the administration of lipid-lowering agents. When standard medical care fails, TPE can be used to reduce levels of triglycerides and prevent pancreatitis recurrence. ${ }^{4}$

In our case, simple observation of the effluent plasma led to the discontinuation of KD to prevent further complications. This case report underlines the importance of observation in clinical practice and raises awareness of possible complications of KD.

\section{References}

1. Mirrakhimov AE, Voore $P$, Halytskyy $O$, Khan M, Ali AM. Propofol infusion syndrome in adults: a clinical update. Crit Care Res Pract. 2015;2015:260385. doi:10.1155/2015/260385

2. Tremblay K, Méthot J, Brisson D, Gaudet D. Etiology and risk of lactescent plasma and severe hypertriglyceridemia. J Clin Lipidol. 2011 Jan-Feb;5(1):37-44. doi: 10.1016/j.jacl.2010.11.004. Epub 2010 Nov 18. PMID: 21262505.

3. Chait A, Subramanian S. Hypertriglyceridemia: Pathophysiology, Role of Genetics, Consequences, and Treatment. [Updated 2019 Apr 23]. In: Feingold KR, Anawalt B, Boyce A, et al., editors. Endotext [Internet]. South Dartmouth (MA): MDText.com, Inc.; 2000. Available from: https://www.ncbi.nlm.nih.gov/books/NBK326743/

4. Stefanutti C, Labbadia G, Morozzi C. Severe hypertriglyceridemia-related acute pancreatitis. Ther Apher Dial. 2013 Apr;17(2):130-7. doi: 10.1111/1744-9987.12008. Epub 2013 Feb 28. PMID: 23551669. 


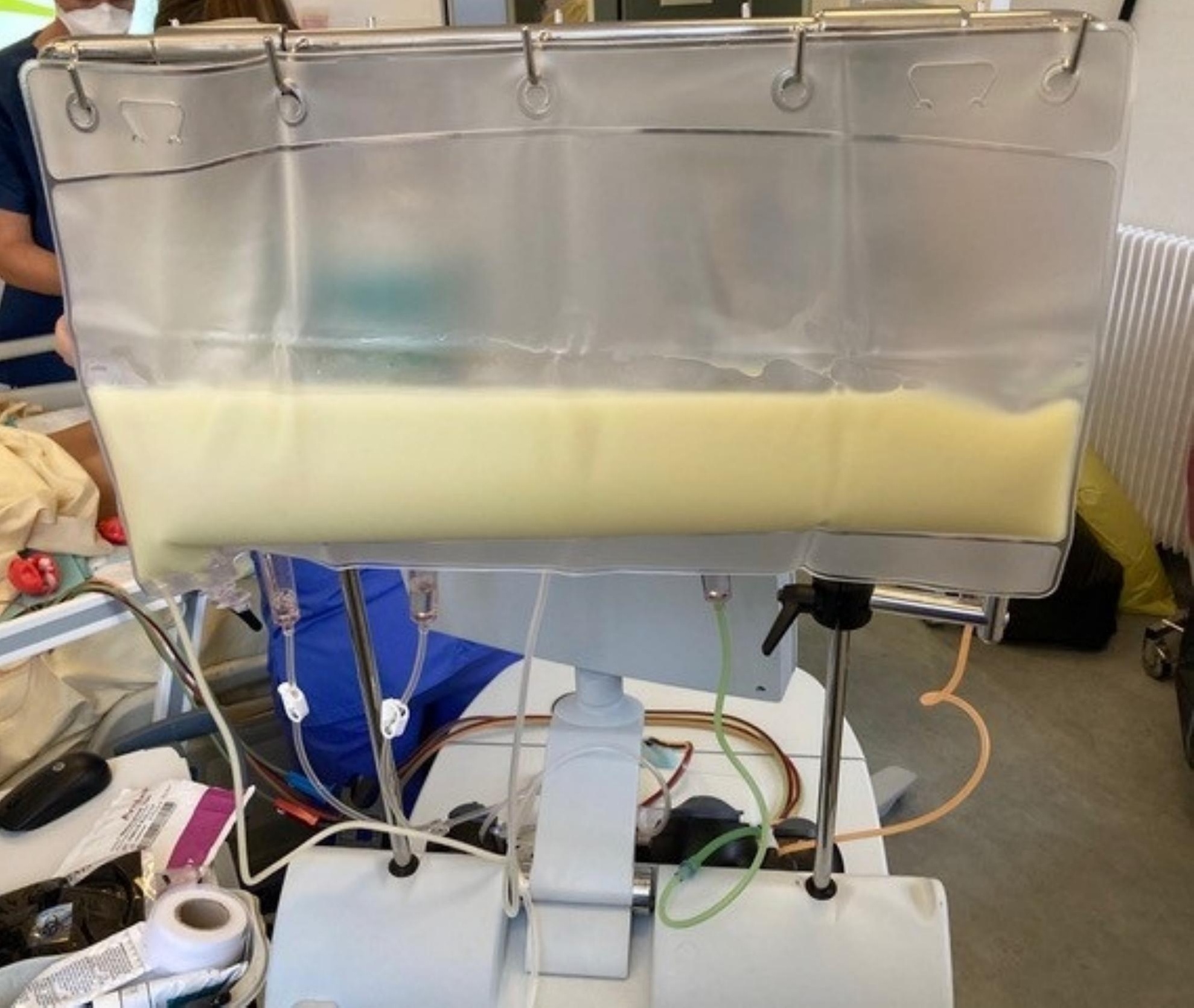

